\title{
Chemical composition and potential ethanol yield of Jerusalem artichoke in a semi-arid region of China
}

\author{
Zu Xin Liu, ${ }^{1}$ Yosef Steinberger, ${ }^{2}$ Xu Chen, ${ }^{1}$ Ji Shi Wang, ${ }^{1}$ Guang Hui Xie ${ }^{1,3}$ \\ ${ }^{1}$ College of Agronomy and Biotechnology, China Agricultural University, Beijing, China; \\ ${ }^{2}$ The Mina and Everard Goodman Faculty of Life Sciences, Bar-Ilan University, \\ Ramat-Gan, Israel; ${ }^{3}$ National Energy R\&D Center for Biomass, China Agricultural \\ University, Beijing, China
}

\begin{abstract}
The study was aimed to evaluate the potential of existing genotypes of Jerusalem artichoke (Helianthus tuberosus L.) as biomass feedstock for ethanol production. We investigated the biomass productivity and chemical composition of twenty-six Jerusalem artichoke clones grown in a semi-arid region of China. Jerusalem artichoke was demonstrated to be a sustainable feedstock for bioethanol production. All structural and non-structural carbohydrates in whole plant of Jerusalem artichoke could be $5000 \mathrm{~L} / \mathrm{ha}$. The above-ground biomass of Jerusalem artichoke could be a promising feedstock for cellulosic ethanol. The ethanol potential yield from cellulose and hemicellulose in aboveground biomass were 1821 to $5930 \mathrm{~L} / \mathrm{ha}$, contributing $29.8-66.4 \%$ of the total ethanol yield, which could be as high as that from switchgrass
\end{abstract}

Correspondence: Guang Hui Xie, College of Agronomy and Biotechnology; National Energy R\&D Center for Biomass, China Agricultural University, 100193 Beijing, P. R. China. Tel.: +86.10.62734888 - Fax: +86.10 .62734850 . E-mail: xiegh@cau.edu.cn

Key words: biomass yield, cellulose, chemical composition, ethanol, Helianthus tuberosus $\mathrm{L}$., total soluble sugar.

Contributions: ZXL, first author of the paper, design and implementation the field experiments and chemical tests; YS, design, analysis pathways, and language edition; XC, JSW, chemical analysis; GHX, corresponding author, experiment supervising and manuscript writing.

Acknowledgements: we thank Chen Lei, Sha Jing and Li Juncheng, for their assistance in the field study and the chemical analysis.

Funding: this study was supported by Chinese Universities Scientific Fund (2012JC010) and the Key Laboratory of Grassland Agro-Ecosystem, Ministry of Agriculture, PRC.

Received for publication: 23 April 2014.

Revision received: 21 January 2015.

Accepted for publication: 29 January 2015.

(C) Copyright Z.X. Liu et al., 2015

Licensee PAGEPress, Italy

Italian Journal of Agronomy 2015; 10:603

doi:10.4081/ija.2015.603

This article is distributed under the terms of the Creative Commons Attribution Noncommercial License (by-nc 3.0) which permits any noncommercial use, distribution, and reproduction in any medium, provided the original author(s) and source are credited. and sweet sorghum stem. Large variation among the investigated genotypes for carbohydrates makes it possible to select suitable clones to be used in bioethanol production in semiarid regions. Clones HB-3, HEN-3, IM-1, SC-1, SHX-3, SX-2 and ZJ-2 yielded tuber total soluble sugar higher than 4.0 tha. Clones BJ-4, HUB-2, HUN-2, QH-1, SD-2 and SHH-1 produced more than 5.0 tha cellulose and hemicellulose in above-ground biomass. Clones BJ-4 and HUB-2 have the highest ethanol potential based on structural carbohydrates. These clones were promising material if used as biofuel feedstock in this growth condition.

\section{Introduction}

The increasing demand for energy, environmental concerns and unpredictable petroleum resources associated with the consumption of fossil fuels have made renewable energy development a priority in China. Corn-based ethanol production primarily occurs in the US, while sugarcane-based ethanol production mostly occurs in Brazil, and sugar beets-based production is used in France (Mussatto et al., 2010; Wang et al., 2012). Chinese policy states that the development of bioenergy in marginal land cannot interfere with food production or cause environmental side effects (National Energy Administration, 2012). Non-food biomass feedstock is a priority for biofuel production.

The Jerusalem artichoke (Helianthus tuberosus L.), which is native to the temperate region of North America, achieves wide geographical adaptation, high biomass yield and inulin content of 50 to $75 \%$ in the tuber dry matter (Danilčenko et al., 2008; Kays and Nottingham, 2008). It can yield fresh tubers between 70 and $80 \mathrm{t} / \mathrm{ha}$, and the above-ground dry matter yield can exceed 25 t/ha when cultivated in the semi-arid region of the Loess Plateau in China (Liu et al., 2012). The ethanol production from the tubers' sugar can reach $6000 \mathrm{~L} / \mathrm{ha}$ (Stolzenburg, 2006). Approximately $2.5 \mathrm{t}$ tuber dry powder is needed to produce $1.0 \mathrm{t}$ refined ethanol via powder batch fermentation technologies (Yuan et al., 2011). Jerusalem artichoke is considered as an attractive energy crop for biofuel production (Baldini et al., 2004; Kays and Nottingham, 2008; Baldini et al., 2011). It is estimated that 17.6 million ha of China's marginal land, primarily in the western, north-east and central mainland, are suitable for Jerusalem artichoke cultivation (Sang and Zhu, 2011; Zhuang et al., 2011).

The great challenge for biomass production is the simultaneous development of crops with a suite of desirable physical and chemical traits and increase biomass yields (Ragauskas et al., 2006). Most biofuel feedstock breeding efforts focused on increased biomass yield, but less research has been invested to improve the profile of structural carbohydrates in the cell walls of energy crops, which impacts processing methods, compared with downstream processing technologies (Ragauskas et al., 2006; Jahn et al., 2011). Ethanol from biomass is 
derived through the bioconversion of sugar. Therefore, higher content of sugar, cellulose and hemicellulose, which are highly variable, due to genetic and environmental influences, will lead to a higher ethanol potential (Nick, 2011; Monono et al., 2013).

Genotype, cultivation, harvest stage and storage condition have strong effects on the biomass production and chemical components of energy crops (Kocsis et al., 2007; Zhao et al., 2009; Lindedam et al., 2010; Han et al., 2011; Zhao et al., 2012). Ethanol yields from corn stover, grasses, winter triticale grain and wheat straw have been observed to vary by cultivar (Lindedam et al., 2010).

Few studies (Slimestad et al., 2010; Matías et al., 2011; Gunnarson et $a l ., 2014$ ) have been conducted to compare chemical composition from different Jerusalem artichoke clones. However, no detailed investigation of changes in both above-ground and tuber biomass composition and potential of bioethanol during the course of cultivation in the Loess Plateau climate conditions is available. The aim of the study was to evaluate the potential of existing genotypes of Jerusalem artichokes biomass feedstock for ethanol production. The variability in the carbohydrates contents and biomass yield, and their distribution in the tubers, stems and leaves of 26 Jerusalem artichoke accessions were analysed for future breeding programs towards biofuel utilisation.

\section{Materials and methods}

\section{Study site and sampling}

The field study was conducted in 2008 and 2011 in Qing Yang, Gansu province, a semi-arid region of the Loess Plateau in western China ( $35^{\circ} 37^{\prime} \mathrm{N}, 107^{\circ} 48^{\prime} \mathrm{E}, 1298 \mathrm{~m}$ asl) on a dark loessial soil (Hu, 1994). A previous paper presented the physical and chemical properties of the 0 to $20 \mathrm{~cm}$ top layer soil, monthly precipitation and temperature pattern and soil water potential at the study site during these two years (Liu $e t$ al., 2012).

Twenty-six Jerusalem artichoke clones (Table 1) (Liu et al., 2012) were tested in a completely randomised block design with three replications in 2008 and four replications in 2011. The plants were harvested in 2008 and 2011 with a crop growth cycle from April 1 to October 1. The harvested plant tissues were divided into tuber, stem, and leaves. Roots were not harvested. Sub-samples from each plant tissue were oven-dried at $75^{\circ} \mathrm{C}$ to a constant weight to calculate the tuber, aboveground biomass (AGB), stem, and leaf yield (Yoshidas et al., 1976). After drying, the plant tissues were ground using a mill (FW100, Test, TianJin, China) and passed through a $0.5 \mathrm{~mm}$ sieve for sugar and starch determination and a $1.0 \mathrm{~mm}$ sieve for cellulose, hemicellulose and lignin determination.

\section{Chemical analyses of plant tissues}

The total soluble sugars and starch contents were determined by the Anthrone method (Jayaraman, 1985). The fibre constituents [neutral detergent fibre residue (NDF), acid detergent fibre residue (ADF), and acid detergent lignin (ADL)] were determined by the Van Soest method (Van Soest et al., 1991) using an Ankom apparatus for extraction and filtering (Ankom 220, Fairport, NY, USA). The cellulose content was calculated as ADF-ADL. The hemicellulose content was calculated as NDFADF. Three replicates of each sample were prepared and tested.

\section{Estimation of the ethanol potential}

$$
E_{\text {sugar }}=\underline{T S \times D M \times 0.51 \times 0.85 \times 1000}
$$

$$
\begin{gathered}
E_{\text {STARCH }}=\frac{S \times D M \times 1.11 \times 0.51 \times 0.85 \times 1000}{0.79} \\
E_{c}=\frac{C \times D M \times 1.11 \times 0.85 \times 0.51 \times 0.85 \times 1000}{0.79}
\end{gathered}
$$

A theoretical ethanol yield in L/ha was calculated using the method described by Zhao et al. (2012). The computation was performed with the following equations: $E_{\text {sugar }}, E_{S T A R C H}, E_{c}$ represent ethanol from sugar, starch, cellulose and hemicellulose. TS, S, C and DM represent content of total soluble sugar, starch, cellulose and hemicellulose, and dry biomass. The values of conversion factor of ethanol from sugar, process efficiency of ethanol from sugar, and process efficiency of sugar from cellulose and hemicellulose is $0.51,0.85$, and 0.85 , respectively. Specific gravity of ethanol is $0.79 \mathrm{~g} / \mathrm{mL}$.

\section{Statistical analysis}

An ANOVA analysis was carried out by mean values and their significant differences were compared with Fisher's least significant difference multiple comparison test to evaluate the effects of genotypes and years. The SAS v9.1.3 software (SAS Institute, Cary, NC, USA), and the significance level was $\mathrm{P}<0.05$ were used.

\section{Results}

\section{Biomass yield}

The tuber yield of Jerusalem artichoke (Table 2) ranged from 3.6 to 10.3 tha in 2008 and from 5.1 to 9.7 t/ha in 2011 . The clone tuber yields significantly differed between years; production was higher in 2008 compared with $2011(\mathrm{P}<0.05)$. Clones GZ-1, HEN-1, HUB-1, IM-1 and SX-2 produced a greater tuber yield (7.8-9.2 tha) compared with the other clones during the test periods. AGB ranged from $58.6 \%$ to $89 \%$ and from $51 \%$ to $76 \%$ of total biomass yield in 2008 and 2011 , respectively. Clones HUB-2, BJ-4, HUN-2, SD-2 and SHH-1 produced the highest AGB (13.9-30.4 t/ha). The stem yield ranged from $36 \%$ to $65 \%$ and from $25 \%$ to $50 \%$ of total dry biomass yield in 2008 and 2011 , respective-

Table 1. The 26 investigated Jerusalem artichoke clones and places of origin.

\begin{tabular}{lccc} 
Clone & Origin & Clone & Origin \\
BJ-2 & Haidian, Beijing & HUN-3 & Yiyang, Hunan \\
BJ-3 & Miyun, Beijing & IM-1 & Moqi, Inner Mongolia \\
\hline BJ-4 & Haidian, Beijing & QH-1 & Pingan, Qinghai \\
CQ-1 & Rongchang, Chongqing & SC-1 & Shuangliu, Sichuan \\
\hline GZ-1 & Guining, Guizhou & SD-1 & Huimin, Shandong \\
HB-2 & Renxian, Hebei & SD-2 & Shandong \\
\hline HB-3 & Renxian, Hebei & SD-3 & Dezhou, Shandong \\
HEN-1 & Zhengzhou, Henan & SHH-1 & Jinshan, Shanghai \\
\hline HEN-3 & Jinshui, Henan & SHX-3 & Baoji, Shaanxi \\
HEN-4 & Zhengzhou, Henan & SX-2 & Taiyuan, Shanxi \\
\hline HUB-1 & Hefeng, Hubei & XJ-2 & Bole, Xinjiang \\
HUB-2 & Jingzhou, Hubei & YN-1 & Dali, Yunnan \\
\hline HUN-2 & Chenzhou, Hunan & ZJ-2 & Wenzhou, Zhejiang \\
\hline
\end{tabular}


ly. The contribution of the stem proportion to the whole plant biomass was higher than the leaf proportions. The highest stem yields were observed in clones GZ-1, HUN-2, SD-2, BJ-4 and HUB-2, ranging from 8.0 to 22.1 tha (Table 2 ).

\section{Total soluble sugar and starch}

Figure 1A and B presents the available total soluble sugar and starch contents found in the tubers. In 2011, a significantly higher total soluble sugar content was observed for different plant parts $(\mathrm{P}<0.001)$ compared with 2008. The clones showed significant differences in the total soluble sugar and starch content of the tubers $(\mathrm{P}<0.001)$. The mean value of total soluble sugar contents in tuber were $595 \mathrm{~g} / \mathrm{kg}$ in 2008 and $466 \mathrm{~g} / \mathrm{kg}$ in 2011. Clones CQ-1, HB-2, HB-3, IM-1, QH-1, and SD-2 had a total tuber soluble sugar content of over $500 \mathrm{~g} / \mathrm{kg}$ in both years. The total soluble sugar content ranged from 43 to $133 \mathrm{~g} / \mathrm{kg}$ and from 56 to $192 \mathrm{~g} / \mathrm{kg}$ in the above-ground dry matter in 2008 and 2011, respectively (Figure 2A and B). Clones GZ-1, HB-3, HEN-1, HUB-1 and HUB-2 at harvest time had total soluble sugar content greater than $10 \%$ in the stems
(Figure 3A and B). The total soluble sugar content in the leaves varied between 27 and $106 \mathrm{~g} / \mathrm{kg}$ in 2008 and from 55 to $135 \mathrm{~g} / \mathrm{kg}$ in 2011 (Figure 4A and B).

The total soluble sugar yield in the tuber dry matter of the individual clones is shown in Figure 5A and B. The total soluble sugar yield of the whole plant ranged from 3.2 to 7.6 t/ha in 2008 and from 3.5 to 7.4 t/ha in 2011 . The sugar yield of tubers varied from $51.3 \%$ to $87.3 \%$ and from $67.2 \%$ to $86.2 \%$ of the whole plant in 2008 and 2011 , respectively, except for the high sugar yield in the above-ground dry matter of HUB-2. Clones HB-3, HEN-3, IM-1, SC-1, SHX-3, SX-2 and ZJ-2 produced tuber total soluble sugar greater than 4.0 t/ha in both years. The sugar yield of the above-ground dry matter was 0.7-4.0 t/ha and 0.8-2.2 t/ha in 2008 and 2011, respectively (Figure $6 \mathrm{~A}$ and $\mathrm{B}$ ).

The starch content of the tubers $(\mathrm{P}<0.001)$, which ranged from 7 to $39 \mathrm{~g} / \mathrm{kg}$ and from 12 to $41 \mathrm{~g} / \mathrm{kg}$, respectively (Figure 1A and B), was significantly higher in 2008 than 2011 . The starch yield of tuber was from 0.2 to 0.9 t/ha in 2008 and from 0.2 to 0.8 t/ha in 2011 (Figures $5 \mathrm{~A}-\mathrm{B}$ and $6 \mathrm{~A}-\mathrm{B})$.

Table 2. Dry matter of tuber yield, above-ground biomass yield, stem yield, and leaf yield ( \pm standard errors) of the 26 Jerusalem artichoke clones in 2008 and 2011.

\begin{tabular}{|c|c|c|c|c|c|c|c|c|}
\hline \multirow[t]{2}{*}{ Clone } & \multicolumn{4}{|c|}{2008} & \multicolumn{4}{|c|}{2011} \\
\hline & TY (t/ha) & $\mathrm{AGB}(\mathrm{t} / \mathrm{ha})$ & SY (t/ha) & LY (t/ha) & TY (t/ha) & AGB (t/ha) & SY (t/ha) & LY (t/ha) \\
\hline BJ-2 & $9.3 \pm 1.32$ & $15.0 \pm 0.33$ & $9.4 \pm 0.21$ & $5.6 \pm 0.13$ & $6.9 \pm 0.44$ & $10.1 \pm 0.61$ & $6.7 \pm 0.42$ & $3.4 \pm 0.22$ \\
\hline BJ-3 & $8.6 \pm 0.85$ & $15.8 \pm 0.95$ & $10.8 \pm 0.65$ & $5.1 \pm 0.30$ & $7.5 \pm 0.30$ & $11.7 \pm 0.13$ & $7.4 \pm 0.21$ & $4.3 \pm 0.29$ \\
\hline BJ-4 & $5.0 \pm 0.64$ & $24.9 \pm 1.45$ & $17.2 \pm 1.01$ & $7.7 \pm 0.45$ & $7.6 \pm 0.44$ & $15.0 \pm 0.34$ & $10.3 \pm 0.34$ & $4.7 \pm 0.11$ \\
\hline CQ-1 & $7.9 \pm 1.10$ & $14.9 \pm 1.58$ & $9.5 \pm 1.01$ & $5.5 \pm 0.58$ & $7.3 \pm 0.55$ & $10.4 \pm 0.59$ & $6.4 \pm 0.39$ & $4.1 \pm 0.25$ \\
\hline GZ-1 & $8.4 \pm 0.82$ & $15.6 \pm 2.09$ & $9.7 \pm 1.30$ & $5.9 \pm 0.80$ & $8.1 \pm 0.14$ & $11.9 \pm 0.56$ & $8.0 \pm 0.54$ & $3.9 \pm 0.34$ \\
\hline HB-2 & $10.3 \pm 2.82$ & $16.3 \pm 1.41$ & $10.5 \pm 0.91$ & $5.9 \pm 0.51$ & $5.5 \pm 0.59$ & $10.1 \pm 0.22$ & $6.1 \pm 0.12$ & $4.0 \pm 0.13$ \\
\hline HB-3 & $10.0 \pm 0.32$ & $17.6 \pm 0.61$ & $11.3 \pm 0.39$ & $6.4 \pm 0.23$ & $6.9 \pm 0.24$ & $10.3 \pm 0.13$ & $6.6 \pm 0.16$ & $3.7 \pm 0.17$ \\
\hline HEN-1 & $8.3 \pm 1.18$ & $17.0 \pm 1.49$ & $11.1 \pm 0.97$ & $6.0 \pm 0.53$ & $8.3 \pm 0.40$ & $11.2 \pm 0.57$ & $7.2 \pm 0.52$ & $4.1 \pm 0.12$ \\
\hline HEN-3 & $8.5 \pm 0.79$ & $17.3 \pm 2.59$ & $10.8 \pm 1.62$ & $6.5 \pm 0.97$ & $7.5 \pm 0.38$ & $9.6 \pm 0.16$ & $6.1 \pm 0.17$ & $3.4 \pm 0.07$ \\
\hline HEN-4 & $8.3 \pm 1.09$ & $18.2 \pm 1.73$ & $12.1 \pm 1.15$ & $6.1 \pm 0.58$ & $7.4 \pm 0.23$ & $11.3 \pm 0.36$ & $7.5 \pm 0.40$ & $3.8 \pm 0.29$ \\
\hline HUB-1 & $8.2 \pm 0.29$ & $14.7 \pm 1.05$ & $9.7 \pm 0.69$ & $5.1 \pm 0.36$ & $9.1 \pm 0.31$ & $12.5 \pm 0.74$ & $7.4 \pm 0.55$ & $5.0 \pm 0.27$ \\
\hline HUB-2 & $3.6 \pm 0.56$ & $30.4 \pm 0.39$ & $22.1 \pm 0.28$ & $8.3 \pm 0.11$ & $5.1 \pm 0.22$ & $15.9 \pm 0.47$ & $10.6 \pm 0.34$ & $5.3 \pm 0.15$ \\
\hline HUN-2 & $6.4 \pm 0.53$ & $19.6 \pm 1.14$ & $13.2 \pm 0.77$ & $6.4 \pm 0.37$ & $5.8 \pm 0.24$ & $13.9 \pm 0.57$ & $9.3 \pm 0.45$ & $4.6 \pm 0.16$ \\
\hline HUN-3 & $7.6 \pm 0.75$ & $12.3 \pm 0.48$ & $7.2 \pm 0.28$ & $5.1 \pm 0.20$ & $8.6 \pm 0.24$ & $11.4 \pm 0.66$ & $7.0 \pm 0.36$ & $4.3 \pm 0.34$ \\
\hline IM-1 & $8.3 \pm 0.45$ & $15.0 \pm 0.63$ & $10.1 \pm 0.42$ & $4.9 \pm 0.21$ & $7.8 \pm 0.30$ & $10.2 \pm 0.52$ & $6.5 \pm 0.37$ & $3.6 \pm 0.24$ \\
\hline QH-1 & $6.2 \pm 0.21$ & $18.0 \pm 3.10$ & $11.4 \pm 1.97$ & $6.6 \pm 1.13$ & $6.6 \pm 0.26$ & $11.5 \pm 0.55$ & $7.2 \pm 0.64$ & $4.3 \pm 0.48$ \\
\hline SC-1 & $9.1 \pm 1.18$ & $16.5 \pm 1.75$ & $10.7 \pm 1.14$ & $5.8 \pm 0.62$ & $7.0 \pm 0.59$ & $10.0 \pm 0.11$ & $5.7 \pm 0.59$ & $4.3 \pm 0.57$ \\
\hline SD-1 & $8.6 \pm 1.24$ & $13.5 \pm 1.28$ & $8.9 \pm 0.84$ & $4.7 \pm 0.44$ & $7.1 \pm 0.24$ & $12.8 \pm 0.43$ & $7.1 \pm 0.63$ & $5.7 \pm 0.58$ \\
\hline SD-2 & $7.5 \pm 0.57$ & $16.5 \pm 1.51$ & $10.6 \pm 0.97$ & $6.0 \pm 0.54$ & $8.7 \pm 0.13$ & $14.3 \pm 0.99$ & $9.6 \pm 0.64$ & $4.6 \pm 0.35$ \\
\hline SD-3 & $7.8 \pm 0.77$ & $14.6 \pm 0.95$ & $9.1 \pm 0.59$ & $5.6 \pm 0.36$ & $7.6 \pm 0.02$ & $12.2 \pm 0.57$ & $7.1 \pm 0.58$ & $5.1 \pm 0.55$ \\
\hline SHH-1 & $6.8 \pm 1.06$ & $19.3 \pm 1.19$ & $12.5 \pm 0.77$ & $6.8 \pm 0.42$ & $9.7 \pm 0.65$ & $14.3 \pm 1.08$ & $7.0 \pm 2.41$ & $7.4 \pm 2.36$ \\
\hline SHX-3 & $8.2 \pm 0.60$ & $14.2 \pm 2.23$ & $8.9 \pm 1.40$ & $5.3 \pm 0.84$ & $7.2 \pm 0.33$ & $10.9 \pm 0.66$ & $7.1 \pm 0.52$ & $3.8 \pm 0.20$ \\
\hline SX-2 & $8.9 \pm 1.57$ & $16.3 \pm 0.96$ & $11.1 \pm 0.65$ & $5.2 \pm 0.31$ & $9.2 \pm 0.70$ & $9.4 \pm 0.06$ & $6.0 \pm 0.23$ & $3.4 \pm 0.18$ \\
\hline $\mathrm{XJ}-2$ & $7.7 \pm 0.39$ & $10.7 \pm 1.95$ & $7.2 \pm 1.32$ & $3.5 \pm 0.64$ & $6.9 \pm 0.78$ & $13.2 \pm 0.27$ & $8.5 \pm 0.11$ & $4.8 \pm 0.16$ \\
\hline YN-1 & $7.1 \pm 1.50$ & $17.0 \pm 0.72$ & $11.6 \pm 0.49$ & $5.5 \pm 0.23$ & $6.6 \pm 1.11$ & $10.9 \pm 0.02$ & $6.6 \pm 0.04$ & $4.3 \pm 0.06$ \\
\hline ZJ-2 & $10.3 \pm 1.05$ & $17.0 \pm 1.66$ & $10.1 \pm 0.98$ & $7.0 \pm 0.68$ & $6.4 \pm 1.16$ & $11.6 \pm 0.19$ & $7.1 \pm 0.22$ & $4.5 \pm 0.21$ \\
\hline Mean \pm SE & $7.9 \pm 0.24$ & $16.8 \pm 0.49$ & $11.0 \pm 0.42$ & $5.8 \pm 0.16$ & $7.4 \pm 0.17$ & $11.9 \pm 0.23$ & $7.4 \pm 0.20$ & $4.4 \pm 0.16$ \\
\hline LSD (0.05) & 2.97 & 4.27 & 6.44 & 1.99 & 1.41 & 1.46 & 1.77 & 1.54 \\
\hline
\end{tabular}

TY, tuber yield; AGB, above-ground biomass yield; SY, stem yield; LY, leaf yield; SE, standard error; LSD, Fisher's least significant difference multiple comparison test. 

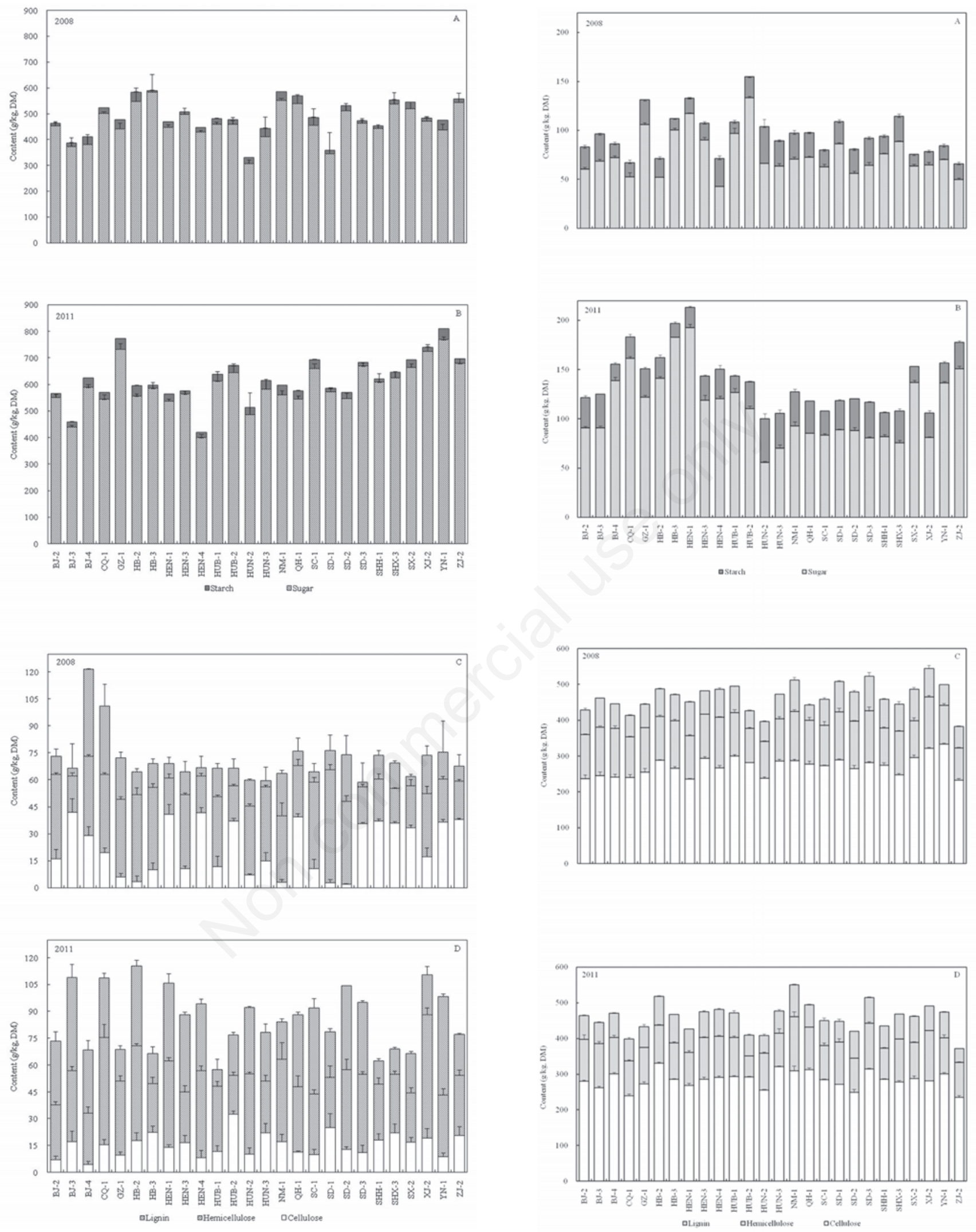

Figure 1. Mean values of the main chemical composition of the tubers of Jerusalem artichoke clones: starch and sugar in 2008 (A) and 2011 (B); lignin, hemicellulose and cellulose in 2008 (C) and 2011 (D). Error bars represent the standard error.

Figure 2. Mean values of the main chemical composition in the above-grounds of Jerusalem artichoke clones: starch and sugar in 2008 (A) and 2011 (B); lignin, hemicellulose and cellulose in 2008 (C) and 2011 (D). Error bars represent the standard error. 


\section{Cellulose, hemicellulose and lignin}

Significant $(\mathrm{P}<0.001)$ differences in structural components (cellulose, hemicellulose and lignin) were found within individual clones over the two years (Table 3). The cellulose content was the highest in the stem, followed by hemicellulose and lignin. The leaf had the lowest lignin content compared to cellulose and hemicellulose.

Cellulose and hemicellulose are generally the main carbohydrate components of the above-ground dry matter. The clones had significant $(\mathrm{P}<0.001)$ differences in the cellulose content of the above-ground dry matter in both years, ranging from 233 to $334 \mathrm{~g} / \mathrm{kg}$ in 2008 and from 235 to $331 \mathrm{~g} / \mathrm{kg}$ in 2011 . The hemicellulose content of above-ground dry matter varied between 90 and $145 \mathrm{~g} / \mathrm{kg}$ in 2008 and 58 and $151 \mathrm{~g} / \mathrm{kg}$ in 2011. The lignin content of the above-ground dry matter differed among clones and ranging from 43 to $97 \mathrm{~g} / \mathrm{kg}$ in 2008 and from 39 to $89 \mathrm{~g} / \mathrm{kg}$ in 2011 (Figure 2C and D).

Stem cellulose content varied from 288 to $481 \mathrm{~g} / \mathrm{kg}$ and averaged 349 $\mathrm{g} / \mathrm{kg}$ in 2008; in 2011, stem cellulose content varied from 284 to $405 \mathrm{~g} / \mathrm{kg}$ and averaged $352 \mathrm{~g} / \mathrm{kg}$. Stem hemicellulose content ranged from 103 to $173 \mathrm{~g} / \mathrm{kg}$ in 2008 and from 55 to $175 \mathrm{~g} / \mathrm{kg}$ in 2011 . The lignin content of stem in the studied clones ranged from 63 to $120 \mathrm{~g} / \mathrm{kg}$ in 2008 and from 47 to $96 \mathrm{~g} / \mathrm{kg}$ in 2011. Total cellulose and hemicellulose contents greater than $500 \mathrm{~g} / \mathrm{kg}$ of the stem dry matter were found in clones XJ-2, HUN3, SD-3, HB-2, YN-1, QH-1 and IM-1 (Figure 3C and D). The cellulose

Table 3. Analysis of variance in the essential components (genotype, year and the combination between the two factors) of Jerusalem artichoke clones.

\begin{tabular}{|c|c|c|c|c|c|c|}
\hline \multirow[t]{2}{*}{ Parameter } & \multicolumn{2}{|c|}{ Genotype } & \multicolumn{2}{|c|}{ Year } & \multicolumn{2}{|c|}{ Genotype $\times$ Year } \\
\hline & F & P-value & F & P-value & F & P-value \\
\hline \multicolumn{7}{|c|}{ Total soluble sugar content } \\
\hline Tuber & $7.99 * * *$ & $<0.001$ & $240.75^{* * *}$ & $<0.001$ & $5.20 * * *$ & $<0.001$ \\
\hline Above-ground & $156.93^{* * *}$ & $<0.001$ & $2643.10 * * *$ & $<0.001$ & $102.46^{* * *}$ & $<0.001$ \\
\hline \multicolumn{7}{|l|}{ Total soluble sugar yield } \\
\hline Tuber & $5.62^{* * *}$ & $<0.001$ & $31.94^{* * *}$ & $<0.001$ & $4.47 * * *$ & $<0.001$ \\
\hline Above-ground & $50.86^{* * *}$ & $<0.001$ & $0.24 \mathrm{~ns}$ & 0.625 & $21.87^{* * *}$ & $<0.001$ \\
\hline \multicolumn{7}{|l|}{ Starch content } \\
\hline Tuber & $52.47^{* * *}$ & $<0.001$ & $39.47^{* * *}$ & $<0.001$ & $0.33 \mathrm{~ns}$ & 0.999 \\
\hline Above-ground & $19.77^{* * *}$ & $<0.001$ & $106.13^{* * *}$ & $<0.001$ & $0.67 \mathrm{~ns}$ & 0.879 \\
\hline \multicolumn{7}{|l|}{ Starch yield } \\
\hline Tuber & $17.19^{* * *}$ & $<0.001$ & $2.77 \mathrm{~ns}$ & 0.099 & $1.73^{*}$ & 0.026 \\
\hline Above-ground & $17.00^{* * *}$ & $<0.001$ & $6.46^{*}$ & 0.012 & $2.31^{* *}$ & 0.001 \\
\hline \multicolumn{7}{|l|}{ Cellulose content } \\
\hline Tuber & $60.04^{* * *}$ & $<0.001$ & $291.27 * * *$ & $<0.001$ & $31.19^{* * *}$ & $<0.001$ \\
\hline Above-ground & $30.48^{* * *}$ & $<0.001$ & $67.76^{* * *}$ & $<0.001$ & $9.01^{* * *}$ & $<0.001$ \\
\hline \multicolumn{7}{|l|}{ Cellulose yield } \\
\hline Tuber & $8.12^{* * *}$ & $<0.001$ & $46.75^{* * *}$ & $<0.001$ & $8.08 * * *$ & $<0.001$ \\
\hline Above-ground & $12.76^{* * *}$ & $<0.001$ & $225.39 * * *$ & $<0.001$ & $4.57^{* * *}$ & $<0.001$ \\
\hline \multicolumn{7}{|l|}{ Hemicellulose content } \\
\hline Tuber & $15.06^{* * *}$ & $<0.001$ & $33.68^{* * *}$ & $<0.001$ & $14.16^{* * *}$ & $<0.001$ \\
\hline Above-ground & $12.45^{* * *}$ & $<0.001$ & $67.00^{* * *}$ & $<0.001$ & $2.43^{* * *}$ & $<0.001$ \\
\hline \multicolumn{7}{|l|}{ Hemicellulose yield } \\
\hline Tuber & $7.95^{* * *}$ & $<0.001$ & $0.14 \mathrm{~ns}$ & 0.714 & $8.26 * * *$ & $<0.001$ \\
\hline Above-ground & $5.78^{* * *}$ & $<0.001$ & $360.81^{* * *}$ & $<0.001$ & $5.24 * * *$ & $<0.001$ \\
\hline \multicolumn{7}{|l|}{ Lignin content } \\
\hline Tuber & $10.39 * * *$ & $<0.001$ & $34.60 * * *$ & $<0.001$ & $2.79 * * *$ & $<0.001$ \\
\hline Above-ground & $13.30 * * *$ & $<0.001$ & $28.20 * * *$ & $<0.001$ & $5.23^{* * *}$ & $<0.001$ \\
\hline \multicolumn{7}{|l|}{ Lignin yield } \\
\hline Tuber & $2.59 * * *$ & $<0.001$ & $85.01^{* * *}$ & $<0.001$ & $3.30^{* * *}$ & $<0.001$ \\
\hline Above-ground & $7.50^{* * *}$ & $<0.001$ & $305.35^{* * *}$ & $<0.001$ & $3.09 * * *$ & $<0.001$ \\
\hline \multicolumn{7}{|l|}{ Ethanol from sugar } \\
\hline Tuber & $5.62 * * *$ & $<0.001$ & $31.94^{* * *}$ & $<0.001$ & $4.47^{* * *}$ & $<0.001$ \\
\hline Above-ground & $50.86^{* * *}$ & $<0.001$ & $0.24 \mathrm{~ns}$ & 0.625 & $21.87 * * *$ & $<0.001$ \\
\hline \multicolumn{7}{|l|}{ Ethanol from starch } \\
\hline Tuber & $17.19^{* * *}$ & $<0.001$ & $2.77 \mathrm{~ns}$ & 0.099 & $1.73^{*}$ & 0.026 \\
\hline Above-ground & $17.00^{* * *}$ & $<0.001$ & $6.46^{*}$ & 0.012 & $2.31^{* *}$ & 0.001 \\
\hline $\begin{array}{l}\text { Ethanol from cellulose } \\
\text { and hemicellulose } \\
\text { in above-ground }\end{array}$ & $9.26 * * *$ & $<0.001$ & $290.89 * * *$ & $<0.001$ & $4.61^{* * *}$ & $<0.001$ \\
\hline
\end{tabular}


and hemicellulose content of the leaves was 8.3 to $16.8 \mathrm{~g} / \mathrm{kg}$ and 5.3 to $17.1 \mathrm{~g} / \mathrm{kg}$ in 2008 , and varied from 11.0 to $20.8 \mathrm{~g} / \mathrm{kg}$ and 2.6 to $14.5 \mathrm{~g} / \mathrm{kg}$ in 2011, respectively (Figure 4C and D).

Total cellulose and hemicellulose yield in the above-ground parts of the 26 artichoke clones ranged from 4.9 to 11.5 t/ha in 2008 and from 3.4 to 6.0 t/ha in 2011. The clones BJ-4, HUB-2, HUN-2, QH-1, SD-2 and SHH-1 produced more than 5.0 t/ha cellulose and hemicellulose in the above-ground parts over the two years with a 0.7-1.7 t/ha lignin yield (Figure 6C and D). The structural carbohydrate yields were much lower in the tuber than in the above-ground part.

\section{Ethanol}

Figures 7 and 8 illustrate the calculated ethanol production expected from the 26 Jerusalem artichoke clones. The total ethanol yield from structural and non-structural carbohydrates in Jerusalem artichoke in 2008 and 2011 ranged from 5267 to $9530 \mathrm{~L} / \mathrm{ha}$ and from 5017 to 7132 L/ha, respectively. In 2008 and 2011, the calculated ethanol yields produced by the total soluble sugar in the tubers were 900 to $3187 \mathrm{~L} / \mathrm{ha}$ and 1511 to $3344 \mathrm{~L} / \mathrm{ha}$, respectively. The highest ethanol yields were achieved by clones HB-2, HB-3, SX-2 and ZJ-2 in
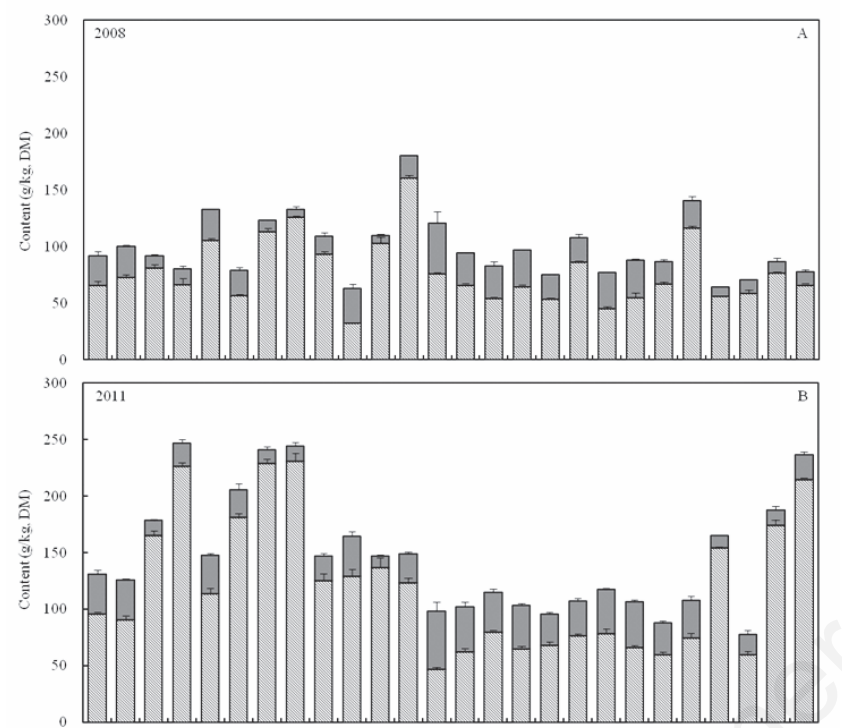

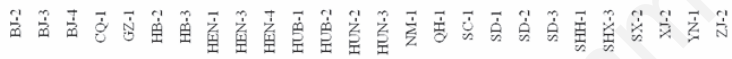
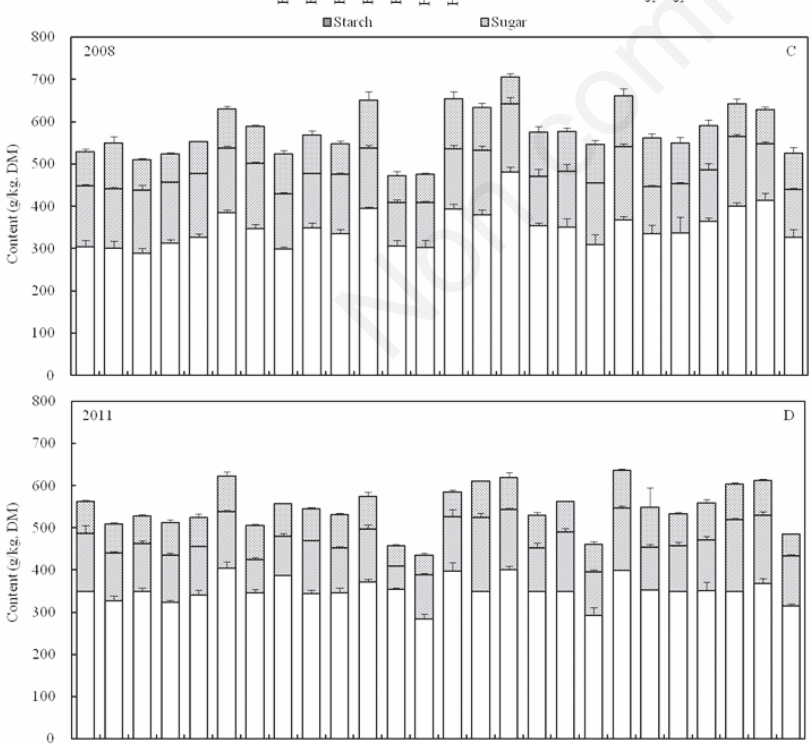

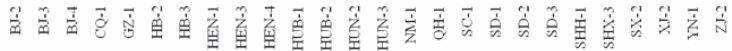

aLignin aHenicellulose aCellulose

Figure 3. Mean values of the main chemical composition in the stems of Jerusalem artichoke clones: starch and sugar in 2008 (A) and 2011 (B); lignin, hemicellulose and cellulose in 2008 (C) and 2011 (D). Error bars represent the standard error.
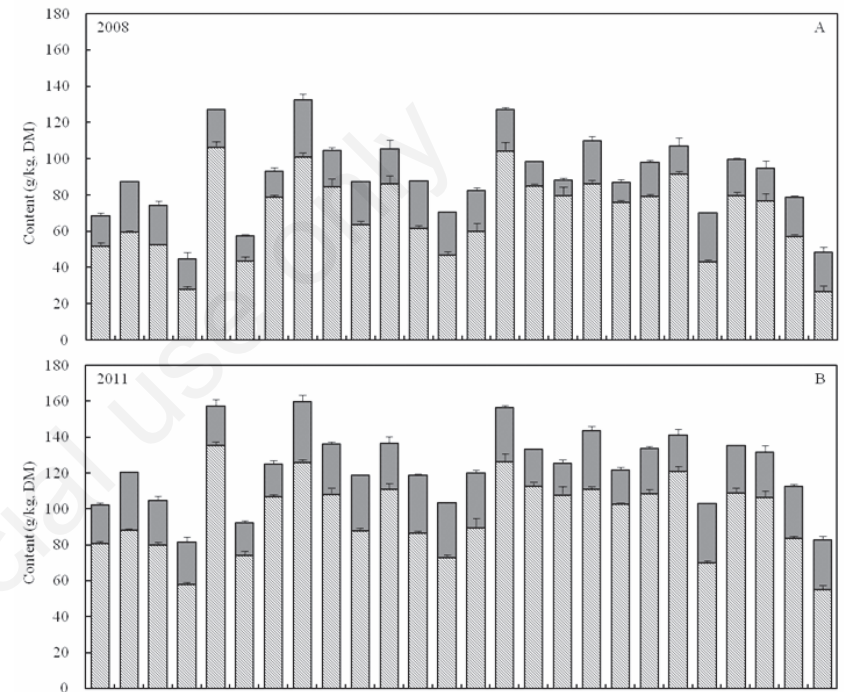

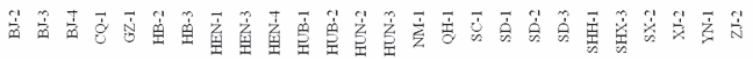
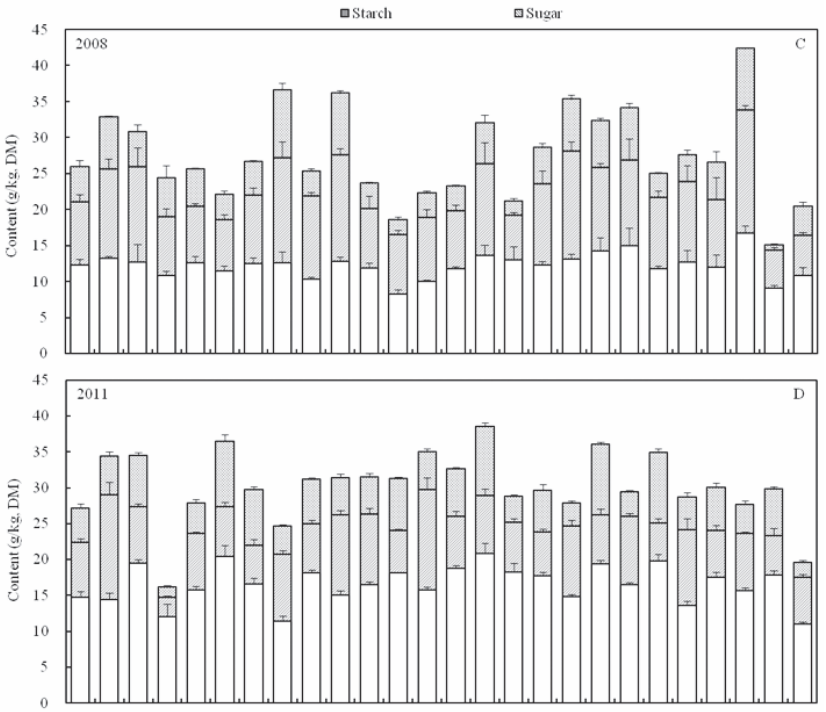

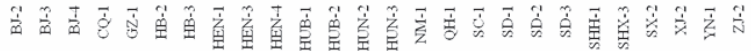

aLiggin aHemicellulose aCellulose

Figure 4. Mean values of the main chemical composition in the leaves of Jerusalem artichoke clones: starch and sugar in 2008 (A) and 2011 (B); lignin, hemicellulose and cellulose in 2008 (C) and 2011 (D). Error bars represent the standard error. 
2008 (2512-3020 L/ha), and by HUB-1, GZ-1, SHH-1 and SX-2 in 2011 (3033-3344 L/ha).

The calculated ethanol yields produced by cellulose and hemicellulose in above-ground parts were 2558 to $5930 \mathrm{~L} / \mathrm{ha}$ and 1821 to 3126 L/ha, respectively, contributing to $41.4 \%-66.4 \%$ (2008) and $29.8 \%$ to $50.8 \%$ (2011) of the total ethanol yield. Clones BJ-4 and HUB-2 have the highest ethanol potential based on structural carbohydrates. The calculated ethanol yield from starch in the whole plant was much lower than the ethanol yield produced from total soluble sugar, cellulose and hemicellulose.
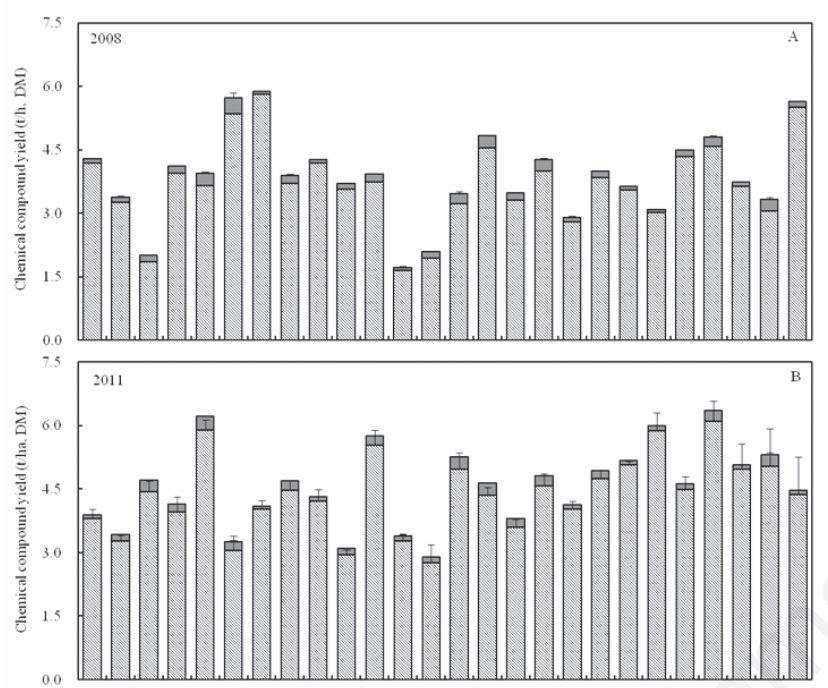

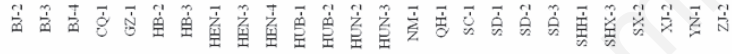
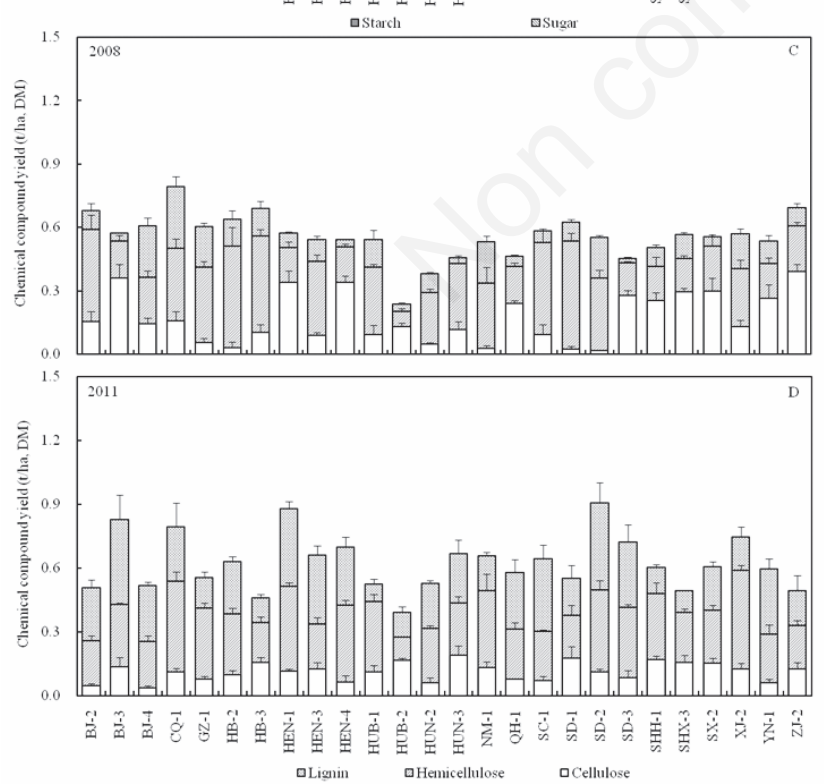

Figure 5. Mean values of the main chemical compound yield in the tubers of Jerusalem artichoke clones: starch and sugar in 2008 (A) and 2011 (B); lignin, hemicellulose and cellulose in 2008 (C) and 2011 (D). Error bars represent the standard error.

\section{Discussion}

The chemical composition of biomass is a key factor that affects the efficiency of biofuel production in conversion processes (Hames et al., 2003; Hamelinck et al., 2005). In this study, each factor of genotype, year and their interactions strongly influenced total soluble sugar, starch, cellulose, hemicellulose, and lignin content of Jerusalem artichoke. It seems that genetic differences and year conditions are responsible for the carbohydrates accumulation and allocation within
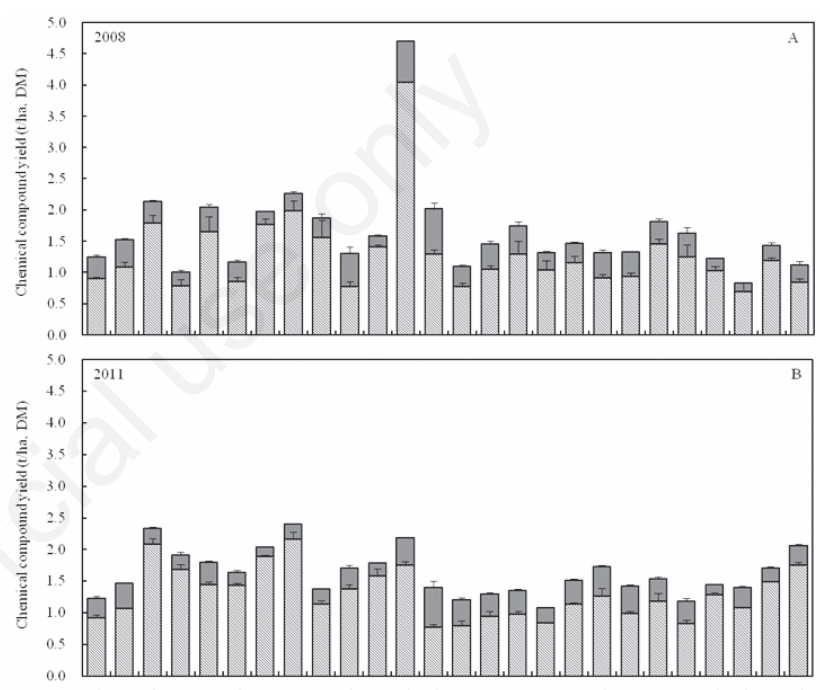

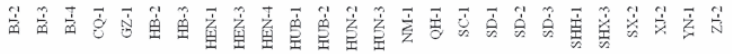
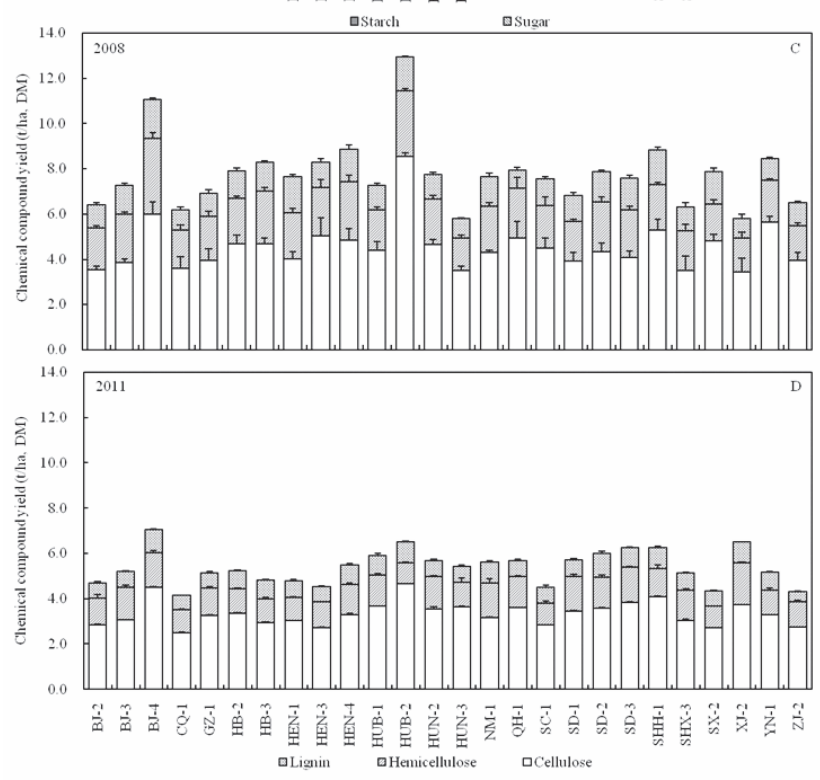

Figure 6. Mean values of the main chemical compound yield in the above-grounds of Jerusalem artichoke clones: starch and sugar in 2008 (A) and 2011 (B); lignin, hemicellulose and cellulose in 2008 (C) and 2011 (D). Error bars represent the standard error. 


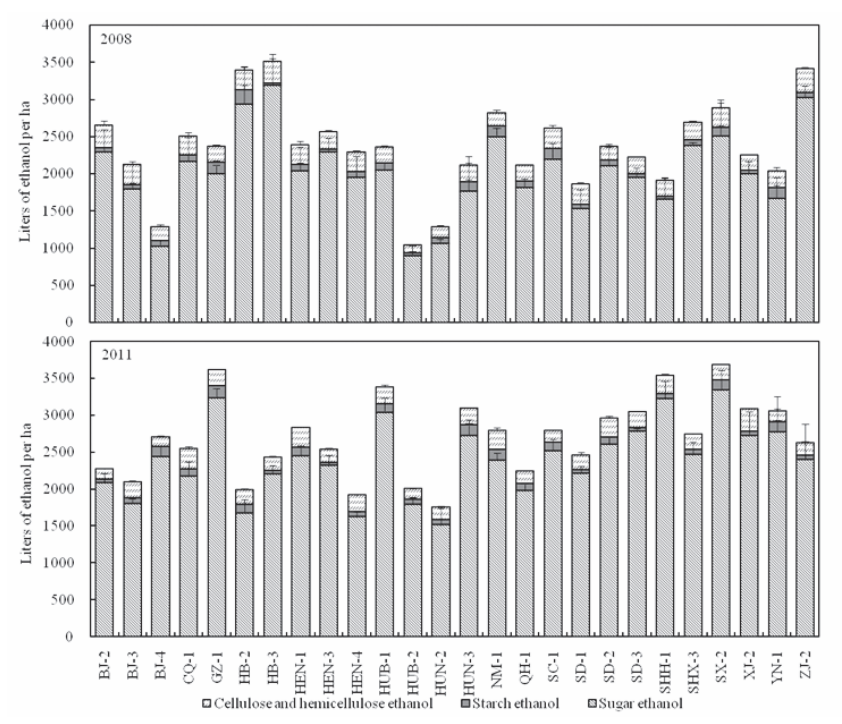

Figure 7. Mean values of the potential ethanol yield from the tubers of Jerusalem artichoke clones in 2008 and 2011. Error bars represent the standard error.

clones. Within the same environment, the clones responded to environmental condition by showing varied performance in a range of chemical components. Hence, the results implied the adaptability of the 26 Jerusalem artichoke clones in this region. During the two experiment seasons, the crops experienced more drought in 2011 than 2008 (Liu et al., 2012) that might be one of the causes of the differences. Differences in specific adaptations of clones imply significant genotype (G) $\times$ environment (E) interactions.

Previous researches demonstrated that the quality and yield of ethanol produced from Jerusalem artichoke is dependent on the tuber yield, tuber quality and fermentation process (Judd, 2003; Szambelan $e t$ al., 2004; Curt et al., 2006; Negro et al., 2006; Stolzenburg, 2006). Total soluble sugar content of tuber in all genotypes varied between 30.7 and $68.0 \%$ in this study. Clones CQ-1, HB-2, HB-3, IM-1, QH-1 and SD-2 presented a total soluble sugar content of over $50 \%$ in tuber dry matter at harvest time. Total sugar content ranging from $13.7 \%$ to $23 \%$ of fresh weight were observed in tubers of 114 Jerusalem artichoke clones, with NPK fertiliser and irrigation to maintain maximum plant growth (Terzić and Atlagiić, 2009). The 57.1-77.8\% total sugar content was reported in tuber dry matter with nine-month growth cycle (Curt et al., 2006). This study showed lower tuber sugar content than the previous study, the direct reason was the harvest time since the plants were removed after a growth cycle of six months (from April to October), when the assimilates in above-ground still kept allocating to tubers when harvested.

Although the papers related to the chemical components of Jerusalem artichoke as forage (Seiler and Campbell, 2004, 2006; Rodrigues et al., 2007; Terzi and Atlagi , 2009; Terzi et al., 2012) or the sugar in its tubers (Barta and Pátkai, 2007; Slimestad et al., 2010; Matías et al., 2011) were reported, the cellulose, hemicellulose and lignin contents in Jerusalem artichoke are rarely documented.

The cellulose and hemicellulose content of Jerusalem artichoke above-ground dry matter has been found to range from $23.3 \%$ to $33.4 \%$ and from $5.9 \%$ to $15.1 \%$, respectively; these figures are similar to the contents (cellulose 24.8\%, hemicellulose 11.2\%) in Jerusalem artichoke reported by Gunnarsson et al. (2014) and sweet sorghum, which
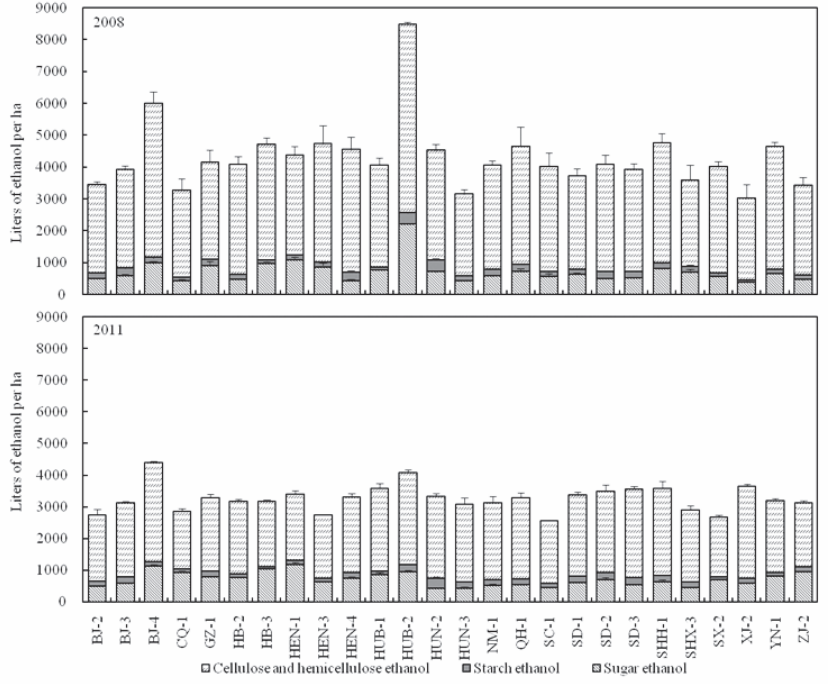

Figure 8. Mean values of the potential ethanol yield from the abovegrounds of Jerusalem artichoke clones in 2008 and 2011. Error bars represent the standard error. presented 20.6\%-26.5\% cellulose and 15.9\%-19.1\% hemicellulose (Zhao et al., 2009).

The efficiency of biomass conversion is positively correlated with the cellulose and hemicellulose content. The cellulose component of the plant cell wall is more easily digested by the bacterium Clostridium cellulolyticum, and twice as much sugar is released following the genetic engineering of lignin biosynthesis in poplar (Boudet et al., 2003). Above-ground part accumulated cellulose and hemicellulose dry matter 3.4 to 11.5 tha, and was competitive to switchgrass (Vogel, 2003).

Lignin, a biological resistant net-like polymer surrounding cellulose and hemicellulose, is inversely correlated with digestibility (Chang and Holtzapple, 2000; Perlack et al., 2005; Chapple et al., 2007). In this study, lignin content in stemis 4.7-12\%, lower than the report on lignin content (17-19\%) in Jerusalem artichoke stem by Gunnarsson et al. (2014), but higher than 1.3-3.3\% reported in the stem dry of sweet sorghum (Zhao et al., 2009). Pedersen et al. (2005) found that a high cellulose/lignin ratio induces plant lodging. Therefore, future breeding studies need to maintain a proper chemical composition ratio.

The investigations in the present study clearly showed that Jerusalem artichoke can potentially produce a comparable ethanol production from cellulose and hemicellulose of above-ground biomass. A potential of 1821-5930 L/ha ethanol from Jerusalem artichoke is close to other cellulosic feedstock used for bioethanol production. An estimated production of 1796 to $6591 \mathrm{~L} /$ ha ethanol from the cellulose and hemicellulose of sweet sorghum harvested after anthesis in North China was reported (Zhao et al., 2009). Vogel (2003) reported that 5000 L/ha ethanol from switchgrass. It is believed that above-ground plant of Jerusalem artichoke could be an alternative way as biomass feedstock compared to tuber, with efficient harvesting cost (Baldini et al., 2004; Kays and Nottingham, 2007).

Large variation among the investigated genotypes for carbohydrates makes it possible to select suitable clones to be used in bioethanol production in semiarid regions. Clones HB-3, HEN-3, IM-1, SC-1, SHX-3, SX-2 and ZJ-2 yielded tuber total soluble sugar higher than 4.0 t/ha. Clones BJ-4, HUB-2, HUN-2, QH-1, SD-2 and SHH-1 produced more than 5.0 tha cellulose and hemicellulose in above-ground biomass. 
These clones were promising material if used as biofuel feedstock in this growth condition.

\section{Conclusions}

Maximised feedstock availability for ethanol requires an energy crop species with both a high biomass yield and high carbohydrate content. This study demonstrates Jerusalem artichoke as a sustainable feedstock for bioethanol production. The above-ground biomass of Jerusalem artichoke was proved to be a promising source for cellulosic ethanol, as the ethanol potential yield could be as high as switchgrass and sweet sorghum. The growth year had significant effects on the biomass and carbohydrate accumulation in tubers and above-ground parts thus the potential ethanol yields. Stability of clones in biomass yield and carbohydrates should be determined when choosing suitable varieties for biofuel crop. Promising materials for bioethanol production in this growth condition could be selected in existing clones.

\section{References}

Baldini M, Danuso F, Rocca A, Bulfoni E, Monti A, Mastro GD, 2011. Jerusalem artichoke (Helianthus tuberosus L.) productivity in different Italian growing areas: a modelling approach. Ital. J. Agron. 6:126-32.

Baldini M, Danuso F, Turi M, Vannozzi GP, 2004. Evaluation of new clones of Jerusalem artichoke (Helianthus tuberosus L.) for inulin and sugar yield from stalks and tubers. Ind. Crop. Prod. 19:25-40.

Barta J, Pátkai GY, 2007. Chemical composition and storability of Jerusalem artichoke tubers. Acta Alimentaria. 36:257-67.

Boudet AM, Kajita S, Grima-Pettenati J, Goffner D, 2003. Lignins and lignocellulosics: a better control of synthesis for new and improved uses. Trends Plant Sci. 8:576-81.

Chang VS, Holtzapple MT, 2000. Fundamental factors affecting biomass enzymatic reactivity. In: $21^{\text {st }}$ Symposium on Biotechnology for Fuels and Chemicals. Humana Press, New York, NY, USA, pp 5-37.

Chapple C, Ladisch M, Meilan R, 2007. Loosening lignin's grip on biofuel production. Nat. Biotechnol. 25:746-8.

Curt MD, Aguado P, Sanz M, Sànchez G, Fernàndez J, 2006. Clone precocity and the use of Helianthus tuberosus L. stems for ethanol. Ind. Crop. Prod. 24:314-20.

Danilčenko H, Jarienė E, Aleknavičienė P, Gajewski M, 2008. Quality of Jerusalem artichoke (Helianthus tuberosus L.) tubers in relation to storage conditions. Not. Botan. Hort. Agrobotan. Cluj-Napoca. 36:23-7.

Gunnarsson IB, Svensson SE, Johansson E, Karakashev D, Angelidaki I, 2014. Potential of Jerusalem artichoke (Helianthus tuberosus L.) as a biorefinery crop. Ind. Crops Prod. 56:231-40.

Hamelinck CN, Hooijdonk GV, Faaij AP, 2005. Ethanol from lignocellulosic biomass: techno-economic performance in short-, middle-, and long-term. Biomass Bioenerg. 28:384-410.

Hames BR, Thomas SR, Sluiter AD, Roth CJ, Templeton DW, 2003. Rapid biomass analysis. New tools for compositional analysis of corn stover feedstocks and process intermediates ethanol production. Appl. Biochem. Biotech. 16:105-8.

Han LP, Steinberger Y, Zhao YL, Xie GH, 2011. Accumulation and partitioning of nitrogen, phosphorus, and potassium in different varieties of sweet sorghum. Field Crop. Res. 120:230-40.

Hu SX, 1994. [Genesis and evolution of Heilu soils in the middle and east of Gansu province.] Acta Pedol. Sinica. 3:295-304. [In Chinese]

Jahn CE, Mckay JK, Mauleon R, Stephens J, McNally KL, Bush DR, Leung H, Leach JE, 2011. Genetic variation in biomass traits among 20 diverse rice varieties. Plant Physiol. 155:157-68.

Jayaraman J, 1985. Laboratory manual in biochemistry. Weicly Estern Ltd., New Delhi, India.

Judd B, 2003. Feasibility of producing diesel fuels from biomass in New Zealand. Available from: http:/www.eeca.govt.nz/sites/all/files/feasibility-of-producing-diesel-fuels-from-biomass-september09.pdf

Kays SJ, Nottingham SF, 2008. Biology and chemistry of Jerusalem artichoke. CRC Press, Athens, GA, USA.

Kocsis L, Liebhard P, Praznik W, 2007. Effect of seasonal changes on content and profile of soluble carbohydrates in tubers of different varieties of Jerusalem artichoke (Helianthus tuberosus L.). J. Agr. Food Chem. 55:9401-8.

Lindedam J, Bruun S, Jørgensen H, Felby C, Magid J, 2010. Cellulosic ethanol: interactions between cultivar and enzyme loading in wheat straw processing. Biotechnol. Biofuels. 3:1-10.

Liu ZX, Spiertz JHJ, Sha J, Xue S, Xie GH, 2012. Growth and yield performance of Jerusalem artichoke clones in a semi-arid region of China. Agron. J. 104:1538-46.

Matías J, González J, Royano Land Barrena RA, 2011. Analysis of sugars by liquid chromatography-mass spectrometry in Jerusalem artichoke tubers for bioethanol production optimization. Biomass. Bioenerg. 35:2006-12.

Monono EM, Nyren PE, Berti MT, Pryor SW, 2013. Variability in biomass yield, chemical composition, and ethanol potential of individual and mixed herbaceous biomass species grown in North Dakota. Ind. Crop. Prod. 41:331-9.

Mussatto SI, Dragone G, Guimarães PMR, Silva JPA, Carneiro LM, Roberto IC, Vicente A, Domingues L, Teixeira JA, 2010. Technological trends, global market, and challenges of bio-ethanol production. Biotechnol. Adv. 28:817-30.

National Energy Administration (NEA), 2012. Biomass energy development in the twelfth five-year plan. National Energy Administration, Bejing, China. Available from: http://zfxxgk.nea.gov.cn/auto87/ 201212/P020121228541608251081.doc [In Chinese]

Negro MJ, Ballesteros I, Manzanares P, Oliva JM, Saez F, Ballesteros M, 2006. Inulin-containing biomass for ethanol production: carbohydrate extraction and ethanol fermentation. In: $27^{\text {th }}$ Symposium on Biotechnology for Fuels and Chemicals. Humana Press, New York, NY, USA, pp 922-932.

Nick R, Don H, Mohammad R, 2011. Optimization of the economic potential of Jerusalem artichoke as a feedstock for the production of biofuels. In: $5^{\text {th }}$ Annual Growing the Margins: Rural Green Energy and $3^{\text {rd }}$ Annual Canadian Farm and Food Biogas, London, ON, Canada.

Pedersen JF, Vogel KP, Funnell DL, 2005. Impact of reduced lignin on plant fitness. Crop Sci. 45:812-9.

Perlack RD, Wright LL, Turhollow AF, Graham RL, Stokes BJ, Erbach DC, 2005. Biomass as feedstock for a bioenergy and bioproducts industry: the technical feasibility of a billion-ton annual supply. 0ak Ridge National Laboratory, Oak Ridge, TN, USA.

Ragauskas AJ, Williams CK, Davison BH, Britovsek G, Cairney J, Eckert CA, Frederick WJ, Hallett JP, Leak DJ, Liotta CL, Mielenz JR, Murphy R, Templer R, Tschaplinski T, 2006. The path forward for biofuels and biomaterials. Science. 311:484-9.

Rodrigues MA, Sousa JE, Cabanas JE, Arrobas M, 2007. Tuber yield and leaf mineral composition of Jerusalem artichoke (Helianthus tuberosus L.) grown under different cropping practices. Span. J. Agric. Res. 5:545-53.

Sang T, Zhu WX, 2011. China's bioenergy potential. GCB Bioenergy. 3:79-90. 
Seiler GJ, Campbell LG, 2004. Genetic variability for mineral element concentrations of wild Jerusalem artichoke forage. Crop Sci. 44:289-92.

Seiler GJ, Campbell LG, 2006. Genetic variability for mineral concentration in the forage Jerusalem artichoke cultivars. Euphytica. 150:281-8.

Slimestad R, Seljaasen R, Meijer K, Skar SL, 2010. Norwegian-grown Jerusalem artichoke (Helianthus tuberosusL.): morphology and content of sugars and fructo-oligosaccharides in stems and tubers. J. Sci. Food. Agr. 90:956-64.

Stolzenburg K, 2006. Topinambur (Helianthus tuberosus L.)Rohstofffür die Ethanolgewinnung. Lap Forchheim, Germany.

Szambelan K, Nowak J, Chrapkowska KJ, 2004. Comparison of bacterial and yeast ethanol fermentation yield from Jerusalem artichoke (Helianthus tuberosus L.) tubers pulp and juices. Acta Sci. Pol. Technol. Aliment. 3:45-53.

Terzić S, Atlagić J, 2009. Nitrogen and sugar content variability in tubers of Jerusalem artichoke (Helianthus tuberosus). Genetika. 41:289-95.

Terzić S, Atlagić J, Maksimović I, Zeremski T, Zorić M, Miklić V, Balalić I, 2012. Genetic variability for concentrations of essential elements in tubers and leaves of Jerusalem artichoke (Helianthus tuberosus L.). Sci. Hortic. 136:135-44.

Van Soest PJ, Robertson JB, Lewis BA, 1991. Methods for dietary fiber, neutral detergent fiber, and non-starch polysaccharides in relation to animal nutrition. J. Dairy Sci. 74:3583-97.

Vogel KP, 2003. Genetic variation among switchgrass for agronomic traits, forage quality, and biomass fuel production. Final report, Oak Ridge National Laboratory, Oak Ridge, TN, USA.

Wang M, Han J, Dunn JB, Cai H, Elgowainy A, 2012. Well-to-wheels energy use and greenhouse gas emissions of ethanol from corn, sugarcane and cellulosic biomass for US use. Environ Res Lett. 7:045905.

Yoshidas S, Forno DA, Cock JH, Gomez KA, 1976. Laboratory manual for physiological studies of rice, 3rd ed. IRRI, Manila, Philippines.

Yuan WJ, Chang BL, Ren JG, Bai FW, 2011. Analysis on ethanol production technology based on fermentation of Jerusalem artichoke. Renew. Energy. Res. 29:139-43.

Zhao YL, Dolat A, Steinberger Y, Xie GH, 2009. Biomass yield and changes in chemical composition of sweet sorghum cultivars grown for biofuel. Field Crop. Res. 111:55-64.

Zhao YL, Steinberger Y, Shi M, Han LP, Xie GH, 2012. Changes in stem composition and harvested produce of sweet sorghum during the period from maturity to a sequence of delayed harvest dates. Biomass Bioenerg. 39:261-73.

Zhuang DF, Jiang D, Liu L, Huang YH, 2011. Assessment of bioenergy potential on marginal land in China. Renew. Sust. Energ. Rev. 15:1050-6. 